\title{
Modulation of immune function by milk fat globule membrane isolates
}

\author{
R. Zanabria, ${ }^{*}$ A. M. Tellez, ${ }^{* 1}$ M. Griffiths, ${ }^{*}$ S. Sharif, $†$ and M. Corredig ${ }^{\star 2}$ \\ *Department of Food Science, and \\ †Department of Pathobiology, University of Guelph, Guelph, ON, N1G 2W5 Canada
}

\begin{abstract}
The nutritional value and characterization of minor milk components on mammalian immune function are not fully understood. The aim of this research was to test the ability of a milk fat globule membrane (MFGM) isolate to modulate murine immune function in vitro, by studying its effects on splenocyte proliferation, apoptosis, and cytokine production. Proliferation of spleen cells was not affected by the MFGM isolate; however, in the presence of polyclonal activators, the MFGM isolate suppressed cell proliferation. Results obtained by flow cytometry did not support programmed cell death as the cause of the MFGM immune-modulating capacity. A mode of suppression on the splenocyte activation process was suggested from a marked decrease in the production of IFN- $\gamma$ and tumor necrosis factor- $\alpha$ cytokines, typical indicators of immune cell activation. The effect of MFGM on IL-4 secretion was significantly less than that for the other 2 cytokines. The activity exerted by the MFGM over concanavalin A-stimulated cells differed from that observed in cells treated with lipopolysaccharide, suggesting a different mode of action depending on the activator used. These results indicate the potential of MFGM extracts as functional ingredients with bioactive modulating capacity.
\end{abstract}

Key words: immunomodulation, milk fat globule membrane, antiinflammatory, bioactivity

\section{INTRODUCTION}

Milk represents a rich source of biologically active molecules that are able to influence a range of physiological functions. An increasing number of its components have been shown to provide immunological protection or other biological activities to neonates and adults. For example, several milk proteins and their enzymatically derived peptides have immunomodula-

Received October 3, 2013.

Accepted November 11, 2013.

${ }^{1}$ Current address: Kraft Foods, 95 Moatfield Drive, Don Mills, ON, M3B 3L6, Canada.

${ }^{2}$ Corresponding author: milena.corredig@uoguelph.ca tory properties (Debbabi et al., 1998; Cross and Gill, 2000; Eriksen et al., 2008) and have shown effects on lymphocyte proliferation and activation, cytokine secretion, antibody production, granulocyte and natural killer cell activity, and phagocytic activity (Cross and Gill, 2000; Gauthier et al., 2006).

Immunoregulation consists of both enhancement and suppression of the immune system, and the final immune response is a result of the balance between enhancing (helper) and suppressive influences (Krakauer and Clough, 1980). In this context, cytokines play an important role in mucosal antibody- and cell-mediated immunity. Following activation, naive $\mathrm{T}$ helper (Th) cells are divided into 2 main categories: $\mathrm{Th}_{1}$ cells, which play a critical role in the regulation of cellular immunity through the secretion of IL-2, IFN- $\gamma$, and tumor necrosis factor (TNF)- $\alpha$ cytokines; and $\mathrm{Th}_{2}$ cells, which regulate antibody-mediated immune response through the production of IL-4, IL-5, and IL-10 (Krakauer and Clough, 1980; Mao et al., 2007). Many factors influence this cell differentiation, including the dose of antigens, the nature and degree of co-stimulation, and the cytokine milieu surrounding the differentiating cells.

Nutrients might modulate immune maturation and responses and provide factors that influence the intestinal microbiome (Rutherfurd-Markwick and Gill, 2005; Zhou and Gao, 2010). Nutraceuticals enriched with milk-derived fractions are thus a target for commercialization, and hence, attention is being given to the characterization of dairy components with bioactive capacity (Cross and Gill, 1999; Benyacoub et al., 2011).

Biofunctionality studies on milk components (i.e., serum proteins and their respective hydrolysates) have either used commercially obtained fractions or highly purified individual components. In most cases, the primary sources have been not been well characterized or the possibility of contamination with other components has not been considered. When performing immunomodulatory studies, it is important to determine the likelihood of bacterial LPS presence on the isolates under study. Contamination might contribute to inconsistent literature data. For example, previous researchers reported that an LPS-free $\beta-L G$ isolate from raw milk had no immune-stimulatory effect on murine bone 
marrow dendritic cells (Brix et al., 2003), contradicting previous findings.

In addition to whey proteins, components of the milk fat globule membrane (MFGM) display several biological activities such as antiviral, anticarcinogenic, and antimicrobial properties (Singh, 2006; Clare et al., 2008; Rasmussen, 2009), as well as important synergies with probiotics (Brisson et al., 2010; Benyacoub et al., 2011).

The native MFGM is a highly structured trilayer membrane that surrounds the native fat globules. Although it represents only 2 to $6 \%$ of the total mass of fat globules, it comprises between 60 and $70 \%$ of the total polar lipids in milk (Spitsberg, 2005; Singh, 2006). A recent patent highlights the immune-protective role of the MFGM extracts in infant formula (Benyacoub et al., 2011), but few studies have focused on the MFGM modulation of lymphocyte biology, and the role of MFGM in the development of the specific host-defense system remains to be clarified.

Considering current trends in product development that look for nutritional value along with the delivery of health benefits, it is desirable to define whether minor milk components and milk by-products have the potential to affect physiological functions, so that their incorporation into manufactured products will provide benefits to human health. For example, patients with chronic inflammatory diseases of the gastrointestinal tract may benefit from dietary products that can counteract the autoimmune host cellular responses and hence limit localized inflammation (Cross and Gill, 1999).

The aim of the present study was to better understand the mechanisms involved in the immune-modulatory capacity of an MFGM isolate from milk.

\section{MATERIALS AND METHODS}

\section{Preparation of MFGM Isolate}

Fresh raw milk samples were collected at the Elora Research Station (Guelph, ON, Canada) under sterile conditions, and isolation was carried out as previously described (Zanabria et al., 2013). For cell stimulation, the freeze-dried material was reconstituted using endotoxin-free water $(2: 1 \mathrm{wt} / \mathrm{vol})$ and protein content was determined by the Lowry assay (DC Protein Assay, BioRad Laboratories, Hercules, CA) using BSA as a standard (BioRad). The amount of LPS was determined before all bioactivity analyses, using the Limulus Amebocyte Lysate Pyrochrome kit (Associates of Cape Cod Inc., Cape Cod, MA). Positive controls and endotoxin-spiked samples were included in the experiments.

\section{Isolation and Culture of Spleen Cells from Healthy Animals}

Female BALB/c mice, 6 to 8 wk old, were obtained from Charles River Laboratories (Montreal, QC, Canada). All mice were housed at the Central Animal Facility of the University of Guelph and studies were carried out in accordance with the Ethics Board (Animal Utilization Protocol No. 10R002, University of Guelph).

Cells were grown in RPMI-1640 medium (Gibco Life Technologies Corp., Burlington, ON, Canada) supplemented with $10 \%$ heat-inactivated fetal bovine serum, $1 \%$ (vol/vol) penicillin-streptomycin (dual antibiotic solution, 10,000 U/mL; Invitrogen Canada Inc., Burlington, $\mathrm{ON}), 2 \mathrm{~m} M$ L-glutamine, and $50 \mu M$ 2-mercaptoethanol (Sigma Aldrich, Oakville, ON, Canada).

Mice were euthanized via $\mathrm{CO}_{2}$ inhalation; the spleens were removed and single-cell suspensions prepared individually under aseptic conditions. Fat tissue was separated and spleens trimmed with a scalpel in 100$\mathrm{mm}$ cell culture dishes (BD Falcon, Fisher Scientific Canada, Toronto, ON, Canada) containing $5 \mathrm{~mL}$ of complete medium. Further disaggregation was achieved by pressing the tissue with a syringe plunger and passing the cell suspension through a $70-\mu \mathrm{m}$ cell strainer, after which it was centrifuged at $300 \times g$ for 7 min at $20^{\circ} \mathrm{C}$. Subsequently, erythrocytes were removed using the red blood cell lysing buffer Hybri-Max (Sigma Aldrich) at room temperature $\left(20^{\circ} \mathrm{C}\right)$. The resulting leukocyte suspension was washed twice with RPMI medium $(300 \times$ $g, 7 \mathrm{~min}, 4^{\circ} \mathrm{C}$ ) and the cell number was adjusted to the required cell density. Viability was assessed by trypan blue exclusion and was always $>90 \%$.

\section{In Vitro Analysis of Splenocyte Proliferation}

Cell proliferation was used as a marker of activation. The capacity of native MFGM isolates to affect cellular immune function was determined by its inclusion in in vitro culture of murine splenic leucocytes. Two different concentrations of the isolate were tested (50 and 100 $\mu \mathrm{g} / \mathrm{mL}$ of MFGM based on protein), based on previous studies showing substantial levels of bioactivity at these 2 concentrations (Zanabria et al., 2013).

A suspension containing freshly isolated splenocytes $\left(100 \mu \mathrm{L}, 5 \times 10^{4}\right.$ cells) was seeded (in quadruplicate) in a 96-well tissue culture plates (Corning Inc., Corning, NY). Medium $(50 \mu \mathrm{L})$ containing either MFGM or one of the mitogenic compounds LPS and concanavalin A (Con A) was added to the wells. The addition of Con A (Sigma) at $2.5 \mu \mathrm{g} / \mathrm{mL}$ or LPS from Escherichia coli 0111:B4 (Sigma) at $20 \mu \mathrm{g} / \mathrm{mL}$ would induce cell proliferation. Prior experiments using LPS $(0-50 \mu \mathrm{g} / \mathrm{mL})$ 
and Con A $(0-10 \mu \mathrm{g} / \mathrm{mL})$ indicated that the chosen concentrations were optimal for splenocyte proliferation analysis after 48 and $72 \mathrm{~h}$ (data not shown). Culture medium served as a negative control. To evaluate the likelihood of an antagonistic or symbiotic effect, MFGM was added either with or without the mitogens. Cells were then incubated for $48 \mathrm{~h}$ in $5 \% \mathrm{CO}_{2}$ and $95 \%$ air at $37^{\circ} \mathrm{C}$ at $100 \%$ humidity.

After stimulation, cell proliferation was assessed using an ELISA 5-bromo-2-deoxyuridine (BrdU) kit (Roche Diagnostics Canada, Quebec, Canada). High background has been reported previously for lymphocyte proliferative analysis (Ling, 1968; Knight, 1987), probably due to the presence of fetal bovine serum containing xenoantigens. These can be acquired by antigenpresenting cells, hence, affecting the kinetics of lymphocyte proliferation. Therefore, to increase sensitivity and to reduce nonspecific binding and background noise, after $48 \mathrm{~h}$ of treatment, the culture plate was centrifuged $\left(300 \times g, 5 \mathrm{~min}, 20^{\circ} \mathrm{C}\right)$ and the medium changed to prewarmed complete medium. A $2 \%$ (wt/vol) BSA solution in PBS was added after the fixation and denaturation of the cells. The extent of nonspecific binding was assessed in samples without cells or BrdU. After 7 washing steps, the labeled molecules were detected by substrate reaction and the final product quantified by measuring the absorbance at $450 \mathrm{~nm}$ using a Multilabel Counter (Wallac 1420 Victor, Perkin-Elmer Life Sciences, Peterborough, ON, Canada). Results were expressed as optical density values, derived from the mean of 3 independent experiments with quadruplicate wells for each treatment.

\section{Quantitation of Apoptosis by Flow Cytometry}

The presence of DNA strand breaks resulting from programmed cell death was assessed by using the Apo-Direct Kit (BD Pharmigen, BD Biosciences, Mississauga, ON, Canada). The lowest MFGM concentration $(50 \mu \mathrm{g} / \mathrm{mL}$ based on protein) found to have an effect on spleen cell proliferation either alone or when combined with mitogens was tested. Immediately after their isolation, spleen cells were seeded in 24 -well plates (in triplicate) at a density of $2 \times 10^{6}$ cells/well containing complete medium or $50 \mu \mathrm{g} / \mathrm{mL}$ of MFGM. Cells were stimulated with $2.5 \mu \mathrm{g} / \mathrm{mL}$ of Con A or $20 \mu \mathrm{g} /$ $\mathrm{mL}$ of LPS with or without MFGM. The total volume was $1 \mathrm{~mL} /$ well for all treatments. After a 48-h stimulation, cells were harvested and washed twice with 1 $\mathrm{mL}$ of cold $\mathrm{PBS}\left(4^{\circ} \mathrm{C}\right)$, and the pellet was collected by centrifugation at $300 \times g$, for $5 \mathrm{~min}$ at $4^{\circ} \mathrm{C}$. The cells were fixed with $1 \%$ paraformaldehyde for $1 \mathrm{~h}$ at $4^{\circ} \mathrm{C}$ and, after 2 washing steps with cold PBS, were resuspended in cold $70 \%$ (vol/vol) ethanol and stored at $-20^{\circ} \mathrm{C}$ for up to $7 \mathrm{~d}$. Cell aliquots $\left(1 \times 10^{6}\right.$ cells $\left./ \mathrm{mL}\right)$ were defrosted, washed twice in washing buffer, and centrifuged $\left(400 \times g, 5 \mathrm{~min}, 20^{\circ} \mathrm{C}\right)$. The DNA was then labeled with $50 \mu \mathrm{L}$ of labeling solution in PBS (as per manufacturer's instructions) and, after incubation at $37^{\circ} \mathrm{C}$ for $1 \mathrm{~h}$, the samples were washed twice with rinse buffer to remove excess label. Cells were resuspended in $400 \mu \mathrm{L}$ of propidium iodide-RNase staining buffer and analyzed by flow cytometry. After gating cells based on DNA doublet discrimination and eliminating noncellular material, green fluorescence was analyzed using a FACScan cytometer and CellQuest software (BD Biosciences). A total of 10,000 cells were counted per sample and the percentage of fluorescein isothiocyanate (FITC)-positive (i.e., apoptotic) cells was determined.

Positive and negative controls (BD Pharmigen ApoDirect kit, BD Biosciences) were run in parallel to the samples to identify regions M1 (for viable cells) and M2 (for cells undergoing apoptosis) and used to define M1/ M2 markers. Additionally, negative and positive apoptotic controls were also developed (freshly isolated and heat-treated splenocytes at $45^{\circ} \mathrm{C}$ for $30 \mathrm{~min}$, respectively; Sodja, 1998). Analysis of the latter did not show significant differences in the setting conditions compared with those defined by the kit manufacturer's control; therefore, all further sample analyses were based on the settings recommended by the manufacturer.

\section{Cytokine Production Assays (ELISA)}

The effect of MFGM on cytokine production was determined via inclusion in in vitro cell culture at a set concentration $(50 \mu \mathrm{g} / \mathrm{mL}$ based on protein) either alone or combined with $2.5 \mu \mathrm{g} / \mathrm{mL}$ of Con A or $20 \mu \mathrm{g} /$ $\mathrm{mL}$ of LPS. The potential modulatory effects of native MFGM were compared against equal quantities (based on protein) of BSA Type V (Sigma), which is known to be nonmodulatory toward murine cells (Wong et al., 1998; Mercier et al., 2004). Stimulants were added to wells of a 24-well tissue culture plate (Corning) containing $2 \times 10^{6}$ cells in suspension (final volume of $1.2 \mathrm{~mL}$ ). Cell culture medium was collected after $48 \mathrm{~h}$, cleared by centrifugation $\left(200 \times \mathrm{g}, 10 \mathrm{~min}, 4^{\circ} \mathrm{C}\right)$, and stored at $-80^{\circ} \mathrm{C}$. Prior analysis confirmed that $48 \mathrm{~h}$ was the optimum stimulation time for the production of the 3 cytokines.

Commercial ELISA kits (BD Biosciences) were used for the quantification of IFN- $\gamma$, TNF- $\alpha$, and IL- 4 in the supernatant, in accordance with the manufacturer's instructions. Briefly, flat-bottomed, high-binding, 96-well plates (Fisher Scientific Canada) were coated with 100 $\mu \mathrm{L}$ of anti-mouse IFN- $\gamma$, TNF- $\alpha$, and IL-4 monoclonal antibodies, respectively, diluted in sodium carbonate buffer ( $\mathrm{pH}$ 9.5) and plates stored overnight at $4^{\circ} \mathrm{C}$. 
Subsequently, plates were washed with PBS containing $0.05 \%$ Tween-20 and wells blocked with $200 \mu \mathrm{L}$ of assay diluent (PBS with 10\% fetal bovine serum, $\mathrm{pH}$ 7.0) by incubating at room temperature for $1 \mathrm{~h}$ with shaking $(200 \mathrm{rpm})$. The plates were washed at least 3 times and patted dry. Samples $(100 \mu \mathrm{L})$ were added to the wells and, after $2 \mathrm{~h}$ of incubation at room temperature, the plate was washed 5 times with PBS. For detection, biotinylated anti-mouse IFN- $\gamma$, TNF- $\alpha$, or IL-4 monoclonal antibodies were used along with the enzyme streptavidin-horseradish peroxidase conjugate. After incubation and washing of the plates, substrate solution (tetramethylbenzidine and hydrogen peroxide) was added for color development. Plates were incubated for $30 \mathrm{~min}$ and stop solution $\left(50 \mu \mathrm{L}\right.$ of $\left.2 \mathrm{~N} \mathrm{H}_{2} \mathrm{SO}_{4}\right)$ applied to each well. Absorbance at $450 \mathrm{~nm}$ was measured using a Wallac 1420 Victor Multilabel Counter (PerkinElmer Life Sciences). Data were converted to cytokine units $\left(10^{-12} \mathrm{~g} / \mathrm{mL}\right)$ by comparison with a standard curve produced using known amounts of recombinant IFN- $\gamma$, TNF- $\alpha$, or IL-4.

\section{Statistical Analysis}

All experiments were performed at least 3 independent times and results expressed as mean \pm standard deviation. Differences among means were tested for statistical significance using a one-way ANOVA and a subsequent Tukey comparison test. All analyses were carried out using Sigma Plot v.10 (Systat Software Inc., San Jose, CA) and IBM SPSS Statistics v.20 (IBM SPSS Inc., Chicago, IL) software. Differences at $P<$ 0.05 were considered statistically significant.

\section{RESULTS AND DISCUSSION}

\section{Effect of MFGM Isolates on Splenocyte Proliferation}

Bacterial LPS is known to be a common contaminant in dairy ingredients (Brix et al., 2003) and a marked stimulator of splenocyte proliferation and cytokine and glutathione production (Möller et al., 1972; Fradet et al., 1976; Gauthier et al., 2006). Lipopolysaccharide analysis of the MFGM isolates showed concentrations of $<15$ endotoxin units $(\mathrm{EU}) / \mathrm{mg}$ of protein $(<1.5 \times$ $10^{-9} \mathrm{~g}$ of LPS/mg of protein), which according to prior reports should not represent a major concern when applied to cell cultures at the doses used in our experiments.

Figure 1 illustrates the effect of 2 MFGM concentrations (50 and $100 \mu \mathrm{g} / \mathrm{mL}$, based on protein) on the proliferation of splenocytes. Under basal conditions, proliferation was not significantly affected by the presence of MFGM $(P>0.05)$. In contrast, the addition of
$2.5 \mu \mathrm{g} / \mathrm{mL}$ of Con A or $20 \mu \mathrm{g} / \mathrm{mL}$ of LPS led to a substantial increase in BrdU uptake (about 95 and $75 \%$, respectively; $P<0.05$ ), indicative of cell proliferation. These results are fully consistent with previous reports (Dutton, 1972; Debbabi et al., 1998; Wong et al., 1998). When the cells were incubated with MFGM in combination with any of the above polyclonal activators, cell proliferation was inhibited and returned to basal levels $(P<0.05$; Figure 1$)$. These results indicated the absence of immunostimulatory components in the isolated MFGM fractions; when murine spleen cells were incubated with MFGM alone, mitogenic activation of the cells did not occur. On the other hand, MFGM plays an important role when the cells have been preactivated. It may also be possible that the MFGM or its components, when combined with either Con A or LPS, becomes toxic to the cells or functions as a proapoptotic stimulus for splenocytes. Hence, further analysis was carried out to assess programmed cell death in an attempt to explain these results.

\section{Apoptosis Assessment by Flow Cytometry}

Flow cytometry analysis with the addition of FITC or propidium iodide to the cells allowed discrimination of early apoptotic cells. The entire scatter population (excluding debris) was considered when analyzing cell death (Telford et al., 2004). Figure 2 shows the distribution of the splenocyte population during the quiescent state (medium only) and after $48 \mathrm{~h}$ of exposure to the

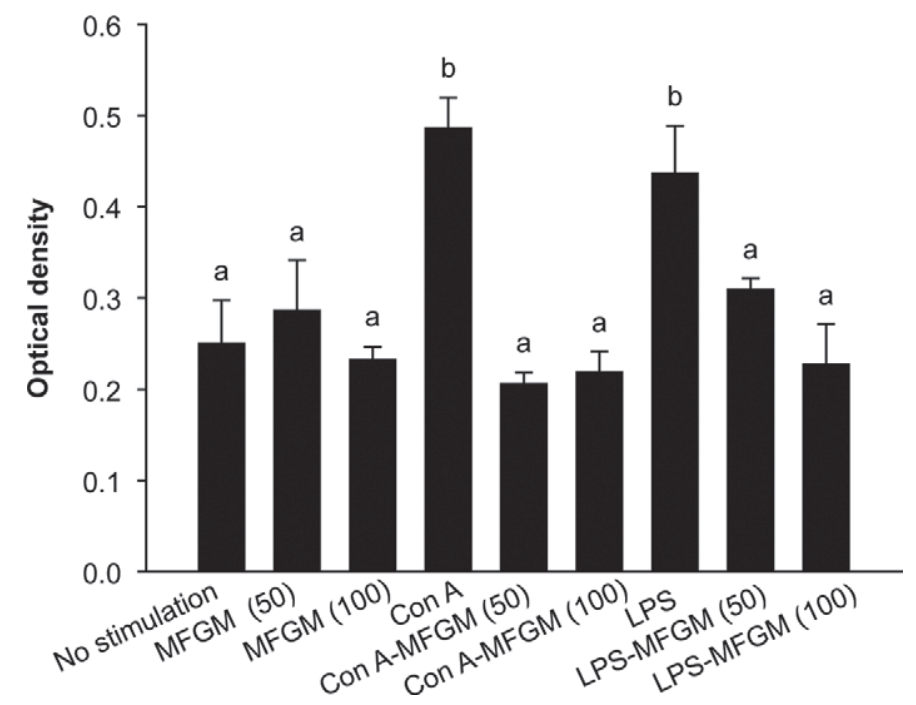

Figure 1. Effect of milk fat globule membrane (MFGM) on splenocyte proliferation. Cells were incubated with concanavalin A (Con A; $2.5 \mu \mathrm{g} / \mathrm{mL})$ or LPS $(20 \mu \mathrm{g} / \mathrm{mL})$ with or without native MFGM (50 and $100 \mu \mathrm{g}$ of protein MFGM/mL) for $48 \mathrm{~h}$. Results (optical density at $450 \mathrm{~nm}$ ) are means $\pm \mathrm{SD}$ of 3 independent experiments. Different letters represent significant differences at $P<0.05$. 
MFGM isolates. In the absence of a mitogen (positive stimulus), lymphocytes remained in a dormant state and part of the population began dying with time, as expected (Ling, 1968). This was clearly shown in the results depicted in Figure 2C, where a bimodal distribution in the population was observed by measuring the FITC signal. Cells treated with the MFGM fraction (without LPS or Con A) showed no significant differences compared with quiescent cells (Figure 2D). A slight change in morphology seemed to occur, as indicated by the forward and side scattering analysis of MFGM-stimulated cells (Figure 2B), although the effect of MFGM on apoptosis was not significant $(P>$ $0.05)$.

Figure 3 summarizes the results of flow cytometry measurements on cell preparations incubated with LPS or Con A, with or without MFGM added $(50 \mu \mathrm{g}$ of protein $/ \mathrm{mL}$ ). Morphological changes occurred when splenocytes were activated by either Con A or LPS (Figure 3A and 3C) compared with control (Figure 2). The scattering signals are likely related to changes in cell size, the prominence of their nucleoli, and the state of cell activity (Ling, 1968). In addition, LPS and Con A activated the cells as clearly indicated by the absence of a second FITC signal peak associated with cell death (Figure 3E, 3G).

When MFGM was present in the cell medium, different effects were observed depending on the type of activator present. When incubated with Con A, some changes were noted in the cell distributions by light scattering (Figure 3A vs. 3B) and the appearance of a second population in the FITC signal (Figure 3E vs.
A

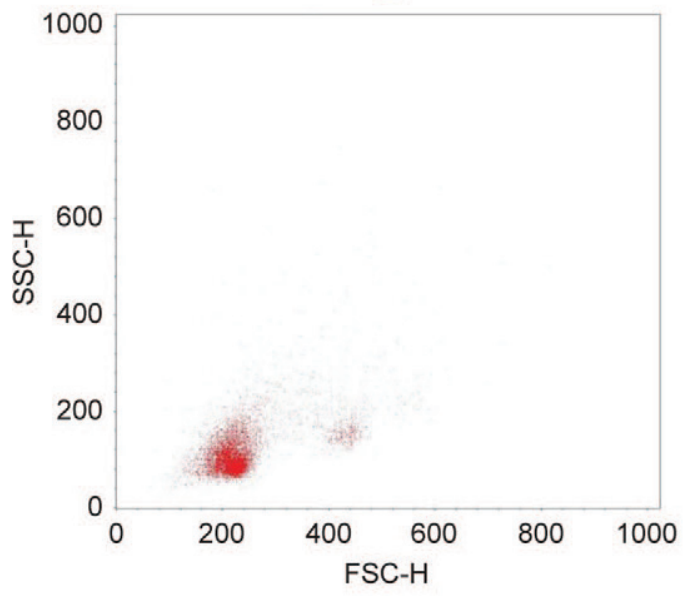

C

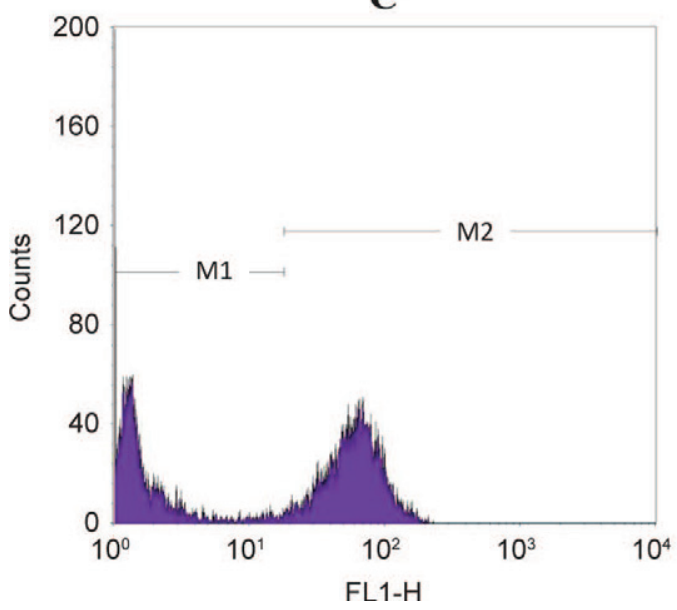

B

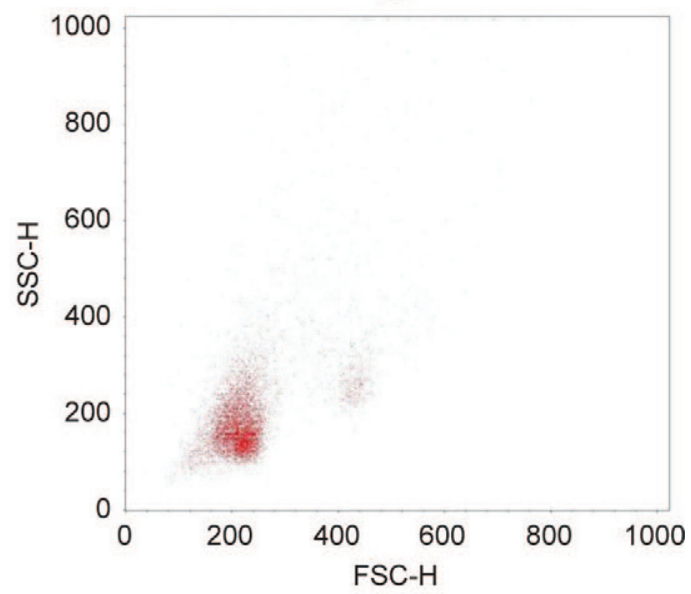

D

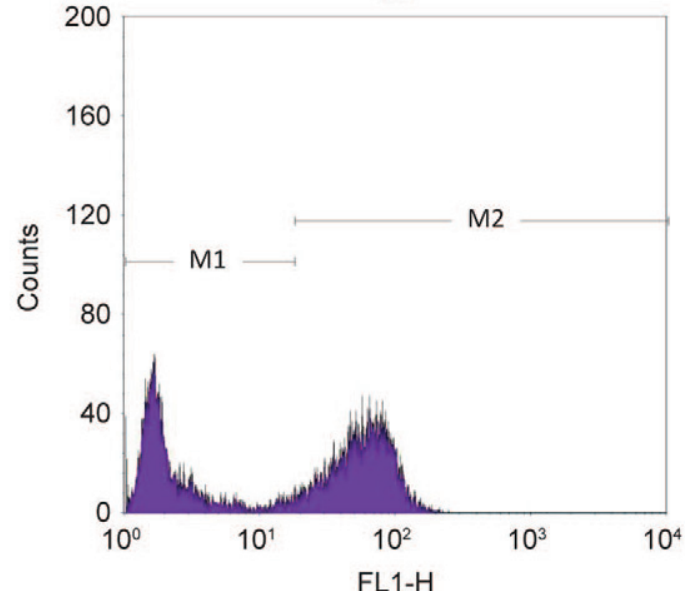

Figure 2. Effect of milk fat globule membrane (MFGM) stimulation on murine splenocytes. Panels A and B show forward (FSC-H) and side (SSC-H) light scattering graphs; panels C and D show fluorescence measurements, where FL1-H denotes the number of fluorescein isothiocyanate (FITC)-positive cells. Cells were nonstimulated (controls) at $48 \mathrm{~h}$ (panels A and C) or stimulated with MFGM (50 $\mu \mathrm{g} / \mathrm{mL}$ based on protein) after $48 \mathrm{~h}$ (panels B and D). For statistical analysis, see Table 1. M1 = viable cell population; M2 = cells undergoing apoptosis. Color version available in the online PDF. 

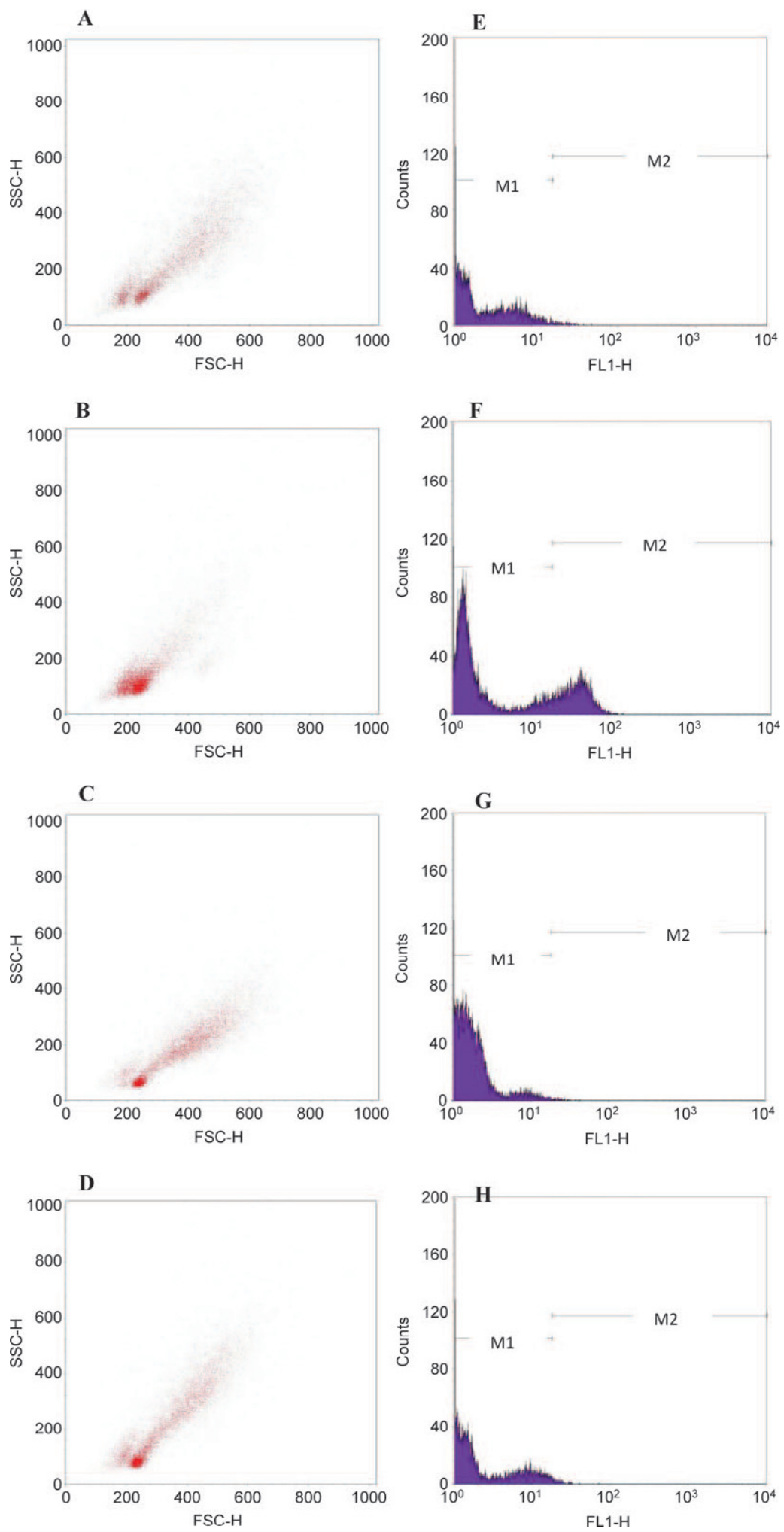

Figure 3. Effect of milk fat globule membrane (MFGM) stimulation on activated murine splenocytes (48 h). Panels A, B, C, and D show forward (FSC-H) and side (SSC-H) light scattering graphs; panels E, F, G, H show fluorescence measurements, where FL1-H denotes the number of fluorescein isothiocyanate (FITC)-positive cells. Cells were treated with concanavalin A (Con A; $2.5 \mu \mathrm{g} / \mathrm{mL}$ ) alone (panels A, E) or with (panels B, F) MFGM $(50 \mu \mathrm{g} / \mathrm{mL}$ based on protein) and with LPS $(20 \mu \mathrm{g} / \mathrm{mL})$ alone (panels C, G) or with (panels D, H) MFGM (50 $\mu \mathrm{g} / \mathrm{mL}$ based on protein). For statistical analysis, see Table 1. M1 = viable cell population; M2 = cells undergoing apoptosis. Color version available in the online PDF. 
$3 \mathrm{~F}$ ), indicating increased DNA breaks. On the other hand, MFGM isolates did not seem to exert an apoptotic effect over the LPS-stimulated cells (Figure 3C vs. 3D for light scattering, and Figure 3G vs. 3H for FITC signal). The differences in behavior between LPS and Con A in the presence of MFGM isolates were statistically significant $(P<0.05)$. A similar dual effect was observed when using a phosphopeptide originating from bovine $\alpha_{\mathrm{S} 1}$-casein; it was shown that the fraction inhibited the Con A-induced proliferation of mouse spleen cells, whereas it enhanced the LPS-induced proliferation (Hata et al., 1998).

Table 1 summarizes the differences in the distribution of the cell population between apoptotic cells (FITC labeled) and viable cells for all treatments. Exposure of splenocytes to MFGM resulted in a modulation of cell response following preactivation by mitogenic compounds. This modulatory effect seemed to be independent of apoptosis when cells were activated with LPS, but not when the cells are activated with Con A.

\section{Cytokine Production}

Cytokines are nonantibody proteins that act as intercellular mediators of the immunological response by promoting cell activation or stimulating their proliferation or differentiation (Hamblin and O'Garra, 1987). More importantly, their final balance defines the immunomodulatory or immunosuppressing capacity of a specific antigen. Figure 4 summarizes the results on the effect of MFGM on cytokine production by stimulated or nonstimulated splenocytes. In all cases, we observed no detectable effect of MFGM on cytokine production in resting splenocytes, and the amount of cytokines produced by these cells was similar to that produced by nonstimulated cells. On the other hand, ligation of the T- and B-cell receptors by Con A and LPS brought about a dramatic increase in the release of all the cytokines tested.

Table 1. Effect of milk fat globule membrane (MFGM) stimulation on murine splenocytes measured by flow cytometry ${ }^{1}$

\begin{tabular}{lcc}
\hline Treatment & M1 $(\%)$ & M2 $(\%)$ \\
\hline Nonstimulated cells & $42.7 \pm 0.8^{\mathrm{a}}$ & $57.3 \pm 0.8^{\mathrm{c}}$ \\
MFGM & $46.0 \pm 2.5^{\mathrm{a}}$ & $54.1 \pm 2.5^{\mathrm{c}}$ \\
LPS & $99.0 \pm 1.2^{\mathrm{c}}$ & $1.0 \pm 1.2^{\mathrm{a}}$ \\
Concanavalin A (Con A) & $99.1 \pm 0.1^{\mathrm{c}}$ & $0.9 \pm 0.1^{\mathrm{a}}$ \\
MFGM + LPS & $99.4 \pm 0.5^{\mathrm{c}}$ & $0.6 \pm 0.5^{\mathrm{a}}$ \\
MFGM + Con A & $69.4 \pm 1.6^{\mathrm{b}}$ & $30.8 \pm 1.7^{\mathrm{b}}$ \\
\hline
\end{tabular}

$\overline{{ }^{a}-\mathrm{c} W i t h i n}$ a column, different letters indicate statistically significant differences $(P<0.05)$.

${ }^{1} \mathrm{M} 1$ represents the viable cell population; M2 represents cells undergoing apoptosis (increase in fluorescein isothiocyanate labeling due to DNA breakage). Results are mean $\pm \mathrm{SD}$ of 3 independent experiments.

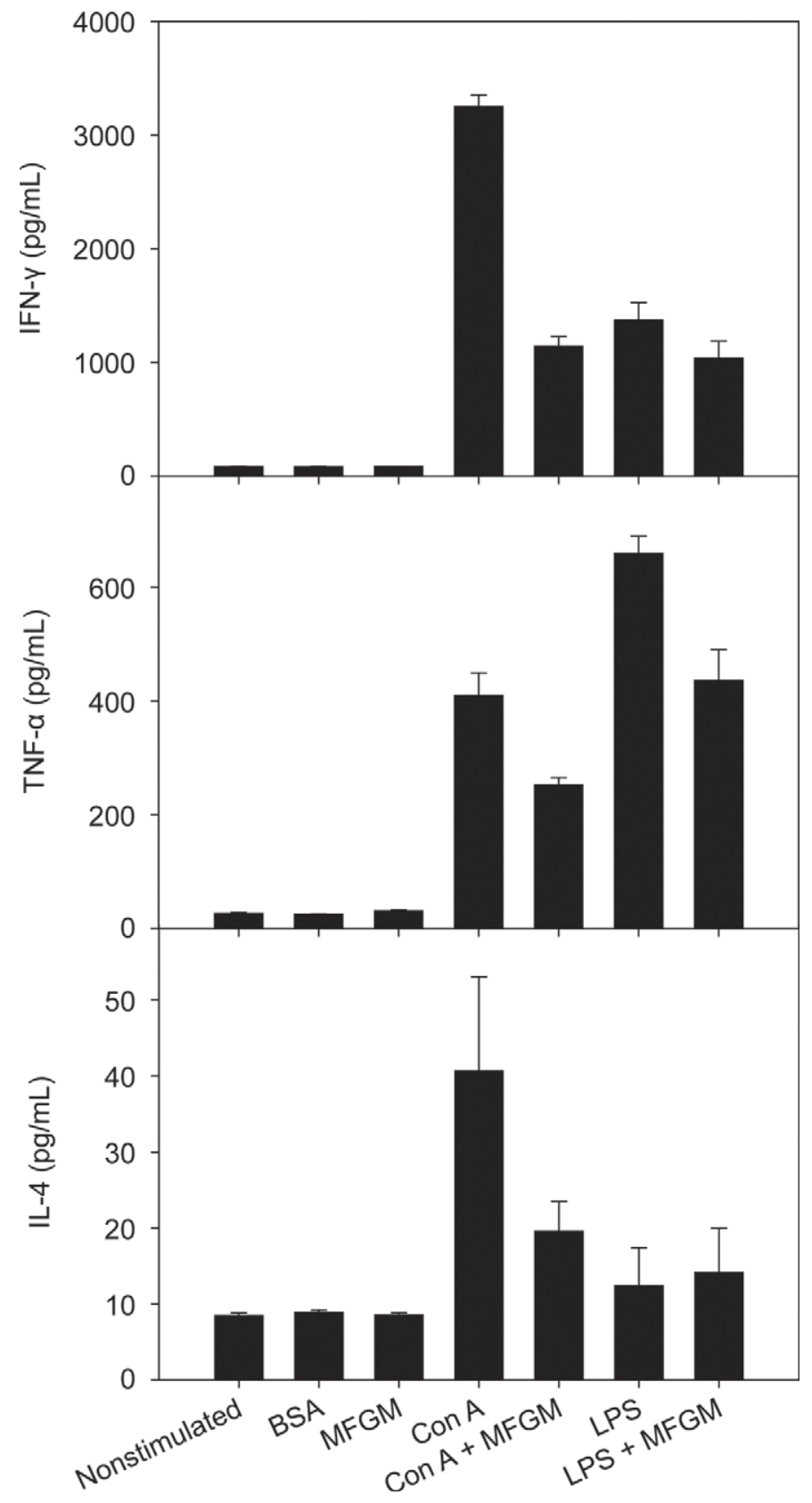

Figure 4. Effect of milk fat globule membrane (MFGM) stimulation on cytokine production by splenocytes: (A) IFN- $\gamma$, (B) tumor necrosis factor- $\alpha$, and (C) IL-4. Cells were incubated for $48 \mathrm{~h}$ with concanavalin A (Con A; $2.5 \mu \mathrm{g} / \mathrm{mL})$ or LPS $(20 \mu \mathrm{g} / \mathrm{mL})$ with $(50 \mu \mathrm{g} /$ $\mathrm{mL}$ based on protein) or without native MFGM or were left untreated (medium only). Results are means and standard deviations of 3 independent experiments. Different letters represent statistical differences at $P<0.05$.

The presence of MFGM isolates effectively counteracted proinflammatory cytokine production, albeit differently depending on the type of activator used (Figure 4). In particular, IFN- $\gamma$ production was over $65 \%$ abrogated when cells were activated with Con A, 
whereas it was inhibited by only $25 \%$ when cells were treated with LPS (Figure 4A). Production of TNF- $\alpha$ was similarly affected, with decreases in concentration of 38 and $34 \%$ when splenocytes were activated with Con A and LPS, respectively (Figure 4B). Levels of IL-4 decreased in MFGM + Con A-treated cells compared with those without MFGM (52\%; Figure 4C), whereas IL-4 production by LPS-stimulated cells did not differ from the basal levels produced by nonstimulated cells $(P>0.05)$. These results suggest that the inhibitory effect of MFGM on proinflammatory cytokine production depends upon the type of stimulation, and that it might affect the $\mathrm{Th}_{1}$ cell group differently by mainly inducing cell-mediated immune responses.

Although several studies have focused on the bioactive capacity of bovine milk constituents, limited work has been done to exclude the effect caused by nonmilk bioactive substances, such as bacterially derived LPS, that are likely to be present in milk preparations. There is no consensus on the minimum amount of LPS capable of having a mitogenic effect on cells of the immune system. Throughout this study, great care was taken to minimize contamination during isolation of the MFGM.

Murine resting splenocytes were not affected by the MFGM, whereas activated cells were susceptible to its influence. It is important to note that the cell cultures used in this study contained a mixed population of spleen cells (antigen-presenting cells, $\mathrm{T}$ and $\mathrm{B}$ cells of many specificities), and the responses observed after incubation with LPS and Con A were significantly different. Different mitogenic substances target different lymphocytic cells in a nonspecific manner; that is, without involving antigen-specific receptors (Dziarski, 1982). Although Con A mainly stimulates T lymphocytes, LPS is a T-cell-independent polyclonal activator of murine B lymphocytes (Dziarski, 1982; Knight, 1987), and it is often referred to as a potent stimulus of inflammation (Vogel and Hogan, 1990). As the regulatory activity was not dependent on the type of activator used (Con A or LPS), results suggest that the MFGM effect is not cell specific, and that an effect on other cell types (besides $\mathrm{T}$ and $\mathrm{B}$ cells) cannot be ruled out.

Although frequently applied, the mitogen-induced lymphocyte proliferation assay does not distinguish between inhibition of early and late phases of the Tcell activation process. Suppression of proliferation could then be caused either by an inhibitory effect on early events in lymphocyte activation, or by blocking cell cycle progression at a certain stage. Alternatively, these effects may be mediated by induction of apoptosis or direct cytotoxic effects. The flow cytometry data demonstrated that the action of MFGM depended on the stimulant used, with MFGM producing significant apoptosis in Con A-treated cells, but failing to cause the same effect in LPS-stimulated cells.

The MFGM might act on specific extranuclear cellular receptors. Indeed, MFGM contains several surfaceassociated membrane proteins derived from mammary epithelial cells (Aoki et al., 1994), and these proteins may interact with cell surface receptors of splenocytes, causing their activation. Proteins from the transferrin family containing mannose, galactose, fucose, $\mathrm{N}$-acetylglucosamine, and $\mathrm{N}$-acetylneuraminic acid may play a role in the inhibitory effect of MFGM on mitogeninduced proliferation, by direct binding of the proteins to the mitogens, causing their deactivation (Otani and Odashima, 1997). Indeed, the capacity of MFGM to bind large amounts of Con A through binding sites that are externally displayed and asymmetrically distributed on the membrane has been reported (Keenan 1974). Terminal residues of $\alpha$-D-mannopyranoside, $\alpha-D-$ glucopyranoside, or $\beta$-D-fructofuranoside represent Con A preferential binding sites, and both the intact fat globule and isolated MFGM have the capacity to bind almost identical amounts of Con A over a range from 30 to $200 \mu \mathrm{g}$ (based on membrane protein concentration; Dutton, 1972; Murray et al., 1979). Furthermore, 7 lectin receptor glycoproteins have been identified in bovine MFGM (Murray et al., 1979) and similar components in human milk have been reported to reduce the proliferation of activated T lymphocytes (Mincheva-Nilsson et al., 1990). It has been hypothesized that these receptors may help prevent immunological overreaction of newborns against environmental antigens encountered at birth (Mincheva-Nilsson et al., 1990).

Similarly, lactadherin (PAS 6/7) can interact with macrophages and dendritic cells through integrin receptors on the cell surface, or induce the differentiation of $\mathrm{CD}^{+} \mathrm{T}$ cells into $\left(\mathrm{CD} 3^{+} \mathrm{CD} 4^{+} \mathrm{CD} 25^{+}\right) \mathrm{T}$ cells, which play an important role in immunosuppression and help to control or prevent the development of spontaneous autoimmune diseases (Zhou and Gao, 2010). The subpopulation of $\mathrm{CD}^{+} \mathrm{T}$ cells that co-express CD25 have a regulatory function, and they appear to play an important role in the induction and maintenance of immune tolerance in the normal intestine, and hence modulate intestinal allergic reactions (Zhou and Gao, 2010).

Although the MFGM bioactivity toward Con A stimulation can be explained, it is not clear whether LPS-induced proliferation would be similarly affected. It has been reported that the N-terminal of human lactoferrin (LF-33), especially the $6 \mathrm{~N}$-terminal residues, is as effective as polymyxin B in neutralizing LPS (Zhang et al., 1999), and this effect seems to be dose dependent (Otani and Odashima, 1997). A similar mechanism 
may be important for the antiinflammatory activity of the MFGM.

Cytokines play a critical role in the development and resolution of immunological responses, working as promoters and regulators of lymphocyte immune function. Three cytokines (TNF- $\alpha$, IFN- $\gamma$, and IL-4) were selected for analysis in this study based on their mode of action upon immune cells. Tumor necrosis factor- $\alpha$ is the first cytokine released in response to bacterial endotoxin (Peck, 1994), whereas IFN- $\gamma$ is important for the activation of $\mathrm{T}$ cells (Mao et al., 2007) by acting upon macrophages to induce enhanced antimicrobial and tumoricidal activity and increase antigen-presenting ability (Coffman et al., 1990). In contrast, IL-4 acts as a rather selective B-cell differentiation factor, promoting the secretion of $\operatorname{IgG}_{1}$ and $\operatorname{IgE}$, thus making $B$ cells more responsive to subsequent mitogenic stimuli. Interleukin- 4 also defines the differentiation of naive $\mathrm{T}$ cells into $\mathrm{Th}_{2}$ cells and may promote the induction of $\mathrm{Th}_{1}$ into $\mathrm{Th}_{2}$ cells by inhibiting the production of proinflammatory cytokines (IL-1 $1 \beta$, TNF- $\alpha$ ). Hence, it functions as a key regulator in humoral and adaptive immunity (Mao et al., 2007). Results of the current study would suggest that MFGM primarily affects the production of $\mathrm{Th}_{1}$ cytokines and a positive correlation exists between inhibition of cell proliferation and of cytokine secretion, clearly suggesting a mechanistic link.

The MFGM is a potential source of proteins, lipids, and enzymes that can effectively influence the immune system response. A consistent pattern of the effects of the membrane on cytokine production would be difficult to describe, due to the mixture of bioactive components present. This study has raised the potential immune-modulatory capacity of MFGM fractions. Under normal physiological conditions, inflammation subsides after the inciting agent is eliminated and the host is restored to its preinflammatory state of physiologic equilibrium (Sipe, 1990). In pathologic situations, however, the inflammatory response can become chronic and lead to tissue injury (Verghese and Snyderman, 1990). Hence, although smaller amounts of proinflammatory cytokines (including TNF- $\alpha$, IFN- $\gamma$ ) are beneficial in response to infection, higher quantities may lead to adverse systemic responses. Downregulation may be beneficial to survival, and hence, specific inhibitors of inflammation-related products or antagonists that prevent the inflammatory reaction may prove extremely useful as antiinflammatory agents.

\section{CONCLUSIONS}

An MFGM fraction isolated from milk was found to exert a regulatory action on splenocytes by affecting their proliferative capacity, mainly through the produc- tion of cytokines. These effects were maximal at $50 \mu \mathrm{g} /$ $\mathrm{mL}$ MFGM (based on protein), and they were dependent on the stimulant present in the medium (LPS or Con A). Future work will require in vivo administration to understand the fate of MFGM as it is digested and absorbed in different areas of the intestinal tract. Initial biotransformation may enhance or decrease the activity of the MFGM, but in immature and more permeable intestinal cell walls, such as those of infants, MFGM may have enhanced antiinflammatory effects compared with those occurring in adults.

\section{ACKNOWLEDGMENTS}

The authors thank of the Canadian Dairy Commission (CDC; Ottawa, ON, Canada), Dairy Farmers of Canada (Ottawa, ON, Canada), the Ontario Dairy Council (Mississauga, ON, Canada), and the Natural Sciences and Engineering Research Council of Canada (NSERC; Ottawa, ON, Canada) for financial support. The authors thank Laura Wright (research farm, University of Guelph, Guelph, ON, Canada) for her help with the milk collection procedure at the experimental farm.

\section{REFERENCES}

Aoki, N., H. Kuroda, M. Urabe, Y. Taniguchi, T. Adachi, R. Nakamura, and T. Matsuda. 1994. Production and characterization of monoclonal antibodies directed against bovine milk fat globule membrane (MFGM). Biochim. Biophys. Acta 1199:87-95.

Benyacoub, J., S. Blum-Sperisen, M. Bosco, L. Bovetto, I. BureauFranz, A. Donnet-Hughes, E. Schiffrin, and L. Favre, inventors. 2011. Infant formula with probiotics and milk fat globule membrane components. Nestec S.A., assignee. Patent No. WO/2011/069987. http://www.google.com/patents/WO2011069987A1.

Brisson, G., H. F. Payken, J. P. Sharpe, and R. Jimenez-Flores. 2010. Characterization of Lactobacillus reuteri interaction with milk fat globule membrane components in dairy products. J. Agric. Food Chem. 58:5612-5619.

Brix, S., L. Bovetto, R. Fritsche, V. Barkholt, and H. Frokiaer. 2003. Immunostimulatory potential of $\beta$-lactoglobulin preparations: Effects caused by endotoxin contamination. J. Allergy Clin. Immunol. 112:1216-1222.

Clare, D. A., Z. Zheng, H. M. Hassan, H. E. Swaisgood, and G. L. Catignani. 2008. Antimicrobial properties of milk fat globule membrane fractions. J. Food Prot. 71:126-133.

Coffman, R. L., A. O'Garra, and D. J. Volkman. 1990. Interleukins and interferons acting on B lymphocytes. Pages 88-103 in Immunophysiology: The Role of Cells and Cytokines in Immunity and Inflammation. J. J. Oppenheim and E. M. Shevach, ed. Oxford University Press, New York, NY.

Cross, M. L., and H. S. Gill. 1999. Modulation of immune function by a modified bovine whey protein concentrate. Immunol. Cell Biol. $77: 345-350$.

Cross, M. L., and H. S. Gill. 2000. Immunomodulatory properties of milk. Br. J. Nutr. 84:S81-S89.

Debbabi, H., M. Dubarry, M. Rautureau, and D. Tome. 1998. Bovine lactoferrin induces both mucosal and systemic immune response in mice. J. Dairy Res. 65:283-293.

Dutton, R. W. 1972. Inhibitory and stimulatory effects of concanavalin-A on the response of mouse spleen cell suspensions to antigen. I. Characterization of the inhibitory cell activity. J. Exp. Med. 136:1445-1460. 
Dziarski, R. 1982. Studies on the mechanism of peptidoglycan- and lipopolysaccharide-induced polyclonal activation. Infect. Immun. 35:507-514.

Eriksen, E. K., G. E. Vegarud, T. Langsrud, H. Almaas, and T. Lea. 2008. Effect of milk proteins and their hydrolysates on in vitro immune responses. Small Rumin. Res. 79:29-37.

Fradet, Y., R. Roy, and F. Daguillard. 1976. Regulation of in vitro lymphocyte-responses. 1. Adjuvant effect of lipopolysaccharide (LPS) on low-zone unresponsiveness to concanavalin-A. Cell. Immunol. 27:94-101.

Gauthier, S. F., Y. Pouliot, and D. Saint-Sauveur. 2006. Immunomodulatory peptides obtained by the enzymatic hydrolysis of whey proteins. Int. Dairy J. 16:1315-1323.

Hamblin, A. S., and A. O'Garra. 1987. Assays for interleukins and other related factors. Pages 209-228 in Lymphocytes: A Practical Approach. G. G. B. Klaus, ed. IRL Press, Oxford, UK.

Hata, I., S. Higashiyama, and H. Otani. 1998. Identification of a phosphopeptide in bovine $\alpha_{S 1}$-casein digest as a factor influencing proliferation and immunoglobulin production in lymphocyte cultures. J. Dairy Res. 65:569-578.

Keenan, T. W. F. 1974. Concanavalin A binding by isolated plasma membranes and endomembranes from liver and mammary gland. FEBS Lett. 44:274-278.

Knight, S. C. 1987. Lymphocyte proliferation assays. Pages 189-207 in Lymphocytes: A Practical Approach. G. G. B. Klaus, ed. IRL Press, Oxford, UK.

Krakauer, R. S., and J. D. Clough. 1980. Suppressor factors: Potential for immunotherapy. Immunopharmacology 2:271-284.

Ling, N. R. 1968. Lymphocyte Stimulation. North-Holland Pub. Co., Amsterdam, the Netherlands.

Mao, X. Y., H. Y. Yang, J. P. Song, Y. H. Li, and F. Z. Ren. 2007. Effect of yak milk casein hydrolysate on $\mathrm{Th}_{1} / \mathrm{Th}_{2}$ cytokines production by murine spleen lymphocytes in vitro. J. Agric. Food Chem. 55:638-642.

Mercier, A., S. F. Gauthier, and L. Fliss. 2004. Immunomodulating effects of whey proteins and their enzymatic digests. Int. Dairy J. $14: 175-183$.

Mincheva-Nilsson, L., M. L. Hammarstrom, P. Juto, and S. Hammarstrom. 1990. Human-milk contains proteins that stimulate and suppress lymphocyte-T proliferation. Clin. Exp. Immunol. 79:463-469.

Möller, G., O. Sjoberg, and J. Andersso. 1972. Mitogen-induced lymphocyte-mediated cytotoxicity in vitro-Effect of mitogens selectively activating T or B cells. Eur. J. Immunol. 2:586-592.

Murray, L. R., K. M. Powell, M. Sasaki, W. N. Eigel, and T. W Keenan. 1979. Comparison of lectin receptor and membrane coatassociated glycoproteins in milk lipid globule membranes. Comp. Biochem. Physiol. B 63:137-145.

Otani, H., and M. Odashima. 1997. Inhibition of proliferative responses of mouse spleen lymphocytes by lacto- and ovotransferrins. Food Agric. Immunol. 9:193-201.
Peck, M. D. 1994. Interactions of lipids with immune function II: Experimental and clinical studies of lipids and immunity. J. Nutr. Biochem. 5:514-521.

Rasmussen, J. T. 2009. Bioactivity of milk fat globule membrane proteins. Aust. J. Dairy Technol. 64:63-67.

Rutherfurd-Markwick, K. J., and H. S. Gill. 2005. Immunomodulating activity of protein concentrates derived from bovine milk whey in mice. Nutr. Res. 25:157-166.

Singh, H. 2006. The milk fat globule membrane-A biophysical system for food applications. Curr. Opin. Colloid Interface Sci. 11:154163.

Sipe, J. D. 1990. The acute-phase response. Pages 259-273 in The Role of Cells and Cytokines in Immunity and Inflammation. J. J. Oppenheim and E. M. Shevach, ed. Oxford University Press, New York, NY.

Sodja, C. B. 1998. Splenic T lymphocytes die preferentially during heat-induced apoptosis: NuMA reorganization as a marker. J. Cell Sci. 111:2305-2313.

Spitsberg, V. L. 2005. Bovine milk fat globule membrane as a potential nutraceutical. J. Dairy Sci. 88:2289-2294.

Telford, W. G., A. Komoriya, and B. Z. Packard. 2004. Multiparametric analysis of apoptosis by flow and image cytometry. Page 141 in Methods in Molecular Biology: Flow Cytometry Protocols. 2nd ed. T. S. Hawley and R. G. Hawley, ed. Humana Press Inc., Totowa, NJ.

Verghese, M. W., and R. Snyderman. 1990. Role of chemotactic and inflammatory cytokines. Pages 274-278 in Immunophysiology: The Role of Cells and Cytokines in Immunity and Inflammation. J. J. Oppenheim and E. M. Shevach, ed. Oxford University Press, New York, NY.

Vogel, S. N., and M. M. Hogan. 1990. Role of cytokines in endotoxinmediated host responses. Pages 238-273 in Immunophysiology: The Role of Cells and Cytokines in Immunity and Inflammation. J. J. Oppenheim and E. M. Shevach, ed. Oxford University Press, New York, NY

Wong, K. F., N. Middleton, M. Montgomery, M. Dey, and R. I. Carr 1998. Immunostimulation of murine spleen cells by materials associated with bovine milk protein fractions. J. Dairy Sci. 81:18251832

Zanabria, R., A. M. Tellez, M. Griffiths, and M. Corredig. 2013. Milk fat globule membrane isolate induces apoptosis in HT-29 human colon cancer cells. Food Funct. 4:222-230.

Zhang, G. H., D. M. Mann, and C. Tsai. 1999. Neutralization of endotoxin in vitro and in vivo by a human lactoferrin-derived peptide. Infect. Immun. 67:1353-1358.

Zhou, Y. J., and J. Gao. 2010. The role of the lactadherin in promoting intestinal DCs development in vivo and vitro. Clin. Dev. Immunol. 2010:357541. http://dx.doi.org/10.1155/2010/357541. 